\title{
An Improved Method for the
}

Determination of $\mathrm{FeO}$ in

Rocks and Minerals

Including Garnet

iy LAURA E. REICHEN and JOSEPH J. FAHEY

こONTRIBUTIONS TO GEOCHEMISTRY

3EOLOGICAL SUR VEY B ULLETIN 1144-B

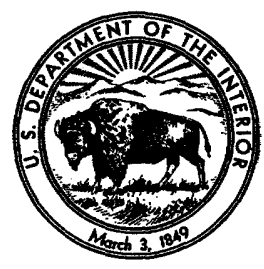




\section{UNITED STATES DEPARTMENT OF THE INTERIOR}

STEWART L. UDALL, Secretary

\section{GEOLOGIGAL SURVEY}

Thomas B. Nolan, Director 


\section{CONTENTS}

Abstract

Page

Introduction

B1

Reagents

Procedure

Results and discussion.

References.

2

3

5

\section{TABLES}

TABLE 1. Analyses of ferrous ammonium sulfate crystals for $\mathrm{FeO}$

2. Analyses of rocks and minerals for $\mathrm{FeO}$ by the conventional and proposed methods. 



\title{
CONTRIBUTIONS TO GEOCHEMISTRY
}

\section{AN IMPROVED METHOD FOR THE DETERMINATION OF FeO IN ROGKS AND MINERALS INGLUDING GARNET}

\author{
By Laura E. Reichen and Joseph J. Fahey
}

\section{ABSTRACT}

A sample, ground to pass a 100-mesh sieve, is treated with $\mathrm{HF}$ and $\mathrm{H}_{2} \mathrm{SO}_{4}$ in a 100-ml platinum crucible to which a measured volume of a standard solution of $\mathrm{K}_{2} \mathrm{Cr}_{2} \mathrm{O}_{7}$ has previously been added. The crucible is covered and the solution is held between $65^{\circ}$ and $70^{\circ} \mathrm{C}$ overnight on the steam bath. The solution is then allowed to cool, the excess dichromate is titrated with standard ferrous ammonium sulfate, and the $\mathrm{Fe}^{+2}$ of the sample computed. It is not necessary to exclude air during the analysis.

\section{INTRODUCTION}

In several of the methods (Graves, 1951, p. 88-94; Hillebrand and others, 1953, p. 907-923) for the determination of $\mathrm{Fe}^{+2}$ in rocks and minerals, the sample is decomposed in a nonoxidizing environment, and subsequently the $\mathrm{Fe}^{+2}$ is determined by titration with a standard oxidant. In these procedures there is probably an error due to a partial oxidation of the $\mathrm{Fe}^{+2}$ because of incomplete exclusion of air before the titration is made. This error, though small when proper precautions are taken to keep it minimal, can be prohibitively high when careless manipulation enters the picture. In the method here described, this source of error is completely eliminated, because, as the sample is decomposed by the acid, the liberated $\mathrm{Fe}^{+2}$ is immediately oxidized by the potassium dichromate present in the solution. It may be significant that consistently higher results are obtained by this method than by the conventional method (table 2). The excess standard potassium dichromate solution that had been initially added is titrated and the $\mathrm{Fe}^{+2}$ of the sample computed. Sulfides, including pyrite, carbonaceous matter, or anything other than $\mathrm{Fe}^{+2}$ oxidizable by dichromate must not be present. 
Wilson (1955) described a procedure in which the sample is treated, in the presence of an excess of ammonium metavanadate, by hydrofluoric and sulfuric acids in the cold and allowed to stand until decomposition of the sample is effected. The stoichimetrically reduced vanadium is titrated back to the pentavalent state and the $\mathrm{Fe}^{+2}$ equivalent is computed. The average period of digestion for the silicates was 2 days, and for a garnetiferous mica schist 6 days was required. Jackson (1957) also used an excess of ammonium metavanadate, hydrofluoric, and sulfuric acids in the cold in the analysis of pulverized fuel ash and slags for $\mathrm{Fe}^{+2}$. Kondrakhina and Songina (1958) determined $\mathrm{Fe}^{+2}$ in chromite ores by oxidizing with $\mathrm{V}_{2} \mathrm{O}_{5}$ and titrating the excess with Mohr's salt (ferrous ammonium sulfate).

\section{REAGENTS}

Standard $\mathrm{K}_{2} \mathrm{Cr}_{2} \mathrm{O}_{7}$ solution: Equivalent to $0.00400 \mathrm{~g} \mathrm{FeO}$ per $\mathrm{ml}$. Dissolve $2.730 \mathrm{~g}$ of $\mathrm{K}_{2} \mathrm{Cr}_{2} \mathrm{O}_{7}$ in 1 liter of water.

$\mathrm{Fe}^{+2}$ solution: About 10 percent stronger than $\mathrm{K}_{2} \mathrm{Cr}_{2} \mathrm{O}_{7}$ solution.

Dissolve $24 \mathrm{~g}$ of $\mathrm{Fe}\left(\mathrm{NH}_{4}\right)_{2}\left(\mathrm{SO}_{4}\right)_{2} \cdot 6 \mathrm{H}_{2} \mathrm{O}$ in water containing $10 \mathrm{ml}$ concentrated $\mathrm{H}_{2} \mathrm{SO}_{4}$ and dilute to 1 liter.

Indicator solution: 0.2 percent solution of sodium diphenylamine sulfonate in water.

\section{PROCEDURE}

Pipet $25 \mathrm{ml}$ of standard potassium dichromate solution into a platinum crucible of 100-ml capacity and add $25 \mathrm{ml}$ of $1: 3 \mathrm{H}_{2} \mathrm{SO}_{4}$. If little or no iron is expected in the sample, add approximately $50 \mathrm{mg}$ powdered ferric sulfate. The $\mathrm{Fe}^{+3}$ minimizes the reaction of the $\mathrm{K}_{2} \mathrm{Cr}_{2} \mathrm{O}_{7}$ with the HF. This was found to be true by experimentation; the cause is unknown. Transfer the weighed sample that has been ground to pass a 100-mesh sieve to the crucible, add $5 \mathrm{ml} \mathrm{HF}$ and stir gently with a stream of water from a wash bottle. The final volume should not be more than $75 \mathrm{ml}$. Be sure that the $\mathrm{Fe}^{+2}$ content does not exceed the oxidizing capacity of the dichromate. Cover with a well-fitting lid and let stand overnight on the steam bath, keeping the temperature of the solution between $65^{\circ}$ and $70^{\circ} \mathrm{C}$. This is done by placing the crucible on top of the closed porcelain covers of the steam bath and adjusting the amount of steam to that which has previously been determined as necessary to maintain a temperature in this range. Temperatures much above or below $65^{\circ}$ to $70^{\circ} \mathrm{C}$ were generally found to be less satisfactory.

Prepare a blank by pipetting another $25 \mathrm{ml}$ of standard $\mathrm{K}_{2} \mathrm{Cr}_{2} \mathrm{O}_{7}$ into a crucible, add the same reagents, including the ferric sulfate, that were added to the sample, and allow to remain on the steam bath 
overnight. This solution is to be used for determining the relative concentration of the ferrous ammonium sulfate solution under specified conditions.

In the morning remove the crucibles from the steam bath and allow the contents to cool. The titrations are made in the crucible and stirred with a magnetic stirrer. Add $5 \mathrm{ml}$ of 85 percent $\mathrm{H}_{3} \mathrm{PO}_{4}$ and a few drops of indicator. The solution should turn purple, indicating an excess of dichromate. Titrate the excess dichromate with the ferrous solution, titrating until the solution turns green and then back-titrate the slight excess of ferrous solution by adding dichromate solution slowly until the green color changes toward a gray green, then one drop at a time until the solution turns purple and the purple persists for 30 seconds. Add this additional volume of dichromate $(0.1-0.5 \mathrm{ml})$ to the original $25.00 \mathrm{ml}$ of solution and calculate the $\mathrm{FeO}$ in the sample.

Calculations:

Standardization of ferrous solution by titration of blank :

$$
\frac{\mathrm{ml} \mathrm{K}_{2} \mathrm{Cr}_{2} \mathrm{O}_{z} \text { solution }}{\text { ml ferrous solution }}=\text { Relative strength of solutions }(R)
$$

Calculation of $\mathrm{FeO}$ in sample:

(ml ferrous solution titrated) $R=\mathrm{ml}$ excess $\mathrm{K}_{2} \mathrm{Cr}_{2} \mathrm{O}_{7}$

(Total $\mathrm{ml} \mathrm{K}_{2} \mathrm{Cr}_{2} \mathrm{O}_{7}$-excess $\mathrm{ml} \mathrm{K}_{2} \mathrm{Cr}_{2} \mathrm{O}_{7}$ ) 0.0040

Sample weight

\section{RESULTS AND DISCUSSION}

Table 1 shows the results obtained with the proposed method with known amounts of $\mathrm{Fe}^{+2}$ using ferrous ammonium sulfate crystals, and table 2 shows the comparison of results on several samples by this method and by the "conventional" procedure. By "conventional" we mean the procedure in which the slurry of sample and water is brought to a boil in a covered crucible to expel the air and then boiled for 10 to 20 minutes after the addition of sulfuric and hydrofluoric acids; the covered crucible is then plunged into a beaker of water containing the necessary acids, and the $\mathrm{Fe}^{+2}$ is titrated with a standard solution of potassium dichromate or potassium permanganate (Groves, 1951). We analyzed the almandite garnet by the conventional procedure in our laboratory even though Pabst (1943) has published an analysis, because our sample, though from the same source, was not from the same tube. The samples of granite and diabase are those prepared for the study of precision and accuracy by Fairbairn and others (1951) and the figures given under conventional are averages of the results obtained by U.S. Geological Sur- 
vey analysts. Angelina C. Vlisidis and M. K. Carron also analyzed the granite and diabase samples by the proposed method.

TABLE 1.-Analyses of ferrous ammonium sulfate crystals for $\mathrm{FeO}$ (milligrams)

$\mathrm{FeO}$ taken

6. 12

12.5

25. 0

40.0

75.0

$\mathrm{FeO}$ found

6.2

12. 5

25. 2

40.2

75.2

6. 0

12. 7

25. 0

40.3

75.2

12. 5

40.1

74. 9

TABLE 2.-Analyses of rocks and minerals for $\mathrm{FeO}$ by the conventional and proposed methods

[Laura E. Reichen, analyst]

\begin{tabular}{|c|c|c|c|c|c|c|}
\hline Method & $\begin{array}{c}\text { Andradite } \\
\text { garnet }\end{array}$ & $\underset{\text { G-1 }}{\text { granite }}$ & $\begin{array}{c}\text { W-1 } \\
\text { diabase }\end{array}$ & $\begin{array}{c}\text { Spessartite } \\
\text { garnet }\end{array}$ & $\begin{array}{c}\text { Biotite } \\
\text { mica }\end{array}$ & $\begin{array}{c}\text { Almandite } \\
\text { garnet }\end{array}$ \\
\hline Conventional_- & 0.54 & 11.06 & 18. 91 & 14.66 & 14. 53 & 230.82 \\
\hline Conventional....- & $\ldots$ & $-\ldots-\ldots$ & --- & $\ldots$ & - - & 30.80 \\
\hline Proposed_. & .74 & 1. 11 & 9. 34 & 15. 04 & 15. 19 & 31.87 \\
\hline Proposed & .78 & 1. 08 & 9. 27 & 14. 98 & 15. 39 & 31.64 \\
\hline Proposed _ _ - &.-- & 1. 04 & 9. 22 & $\ldots$ & 15. 14 & \\
\hline Proposed _. . & & 31.09 & ${ }^{3} 9.34$ & & & \\
\hline Proposed _. - & 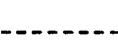 & ${ }^{4} 1.25$ & 49. 34 & & & \\
\hline Proposed, no HF.- & 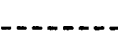 & $---n--$ & $-\pi$ & & 15. 08 & \\
\hline Proposed, no HF_ & & 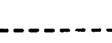 & & - & 15. 27 & \\
\hline
\end{tabular}

1 Fairbairn and others (1951, p. 38, table 17).

2 A. F. Kountze, analyst (Pabst, 1943).

8 M. K. Carron, analyst.

- Angelina C. Visidis, analyst.

There is a slight reaction between the $\left(\mathrm{Cr}_{2} \mathrm{O}_{7}\right)^{-2}$ and the hydrofluoric acid when the two are in contact on the steam bath overnight. The addition of $\mathrm{Fe}^{+3}$ to the dichromate solution before the addition of hydrofluoric acid tends to prevent this reaction. The addition of boric acid to complex the fluorine is not satisfactory because the boric acid ties up the fluoride so effectively that the attack of the silicate is prevented. When potassium permanganate was used as the oxidant instead of potassium dichromate, permanganate equivalent to $7 \mathrm{mg}$ $\mathrm{FeO}$ reacted with the hydrofluoric acid.

A correction must be made for the dichromate destroyed by the hydrofluoric acid (maximum $2 \mathrm{mg}$ equivalent of $\mathrm{FeO}$ ). The usual practice in such a case is to subtract a blank which has been obtained by running through the procedure with the reagents only. However, the destruction of dichromate appears to be proportional to the amount of excess dichromate so that the direct subtraction of a blank is not satisfactory. By using the ratio $(R)$ of the heated dichromate to the $\mathrm{Fe}^{+2}$ solution to calculate the dichromate equivalent of the $\mathrm{Fe}^{+2}$ 
solution used for the titration of a sample, the effect of subtracting a blank proportional to the excess of dichromate is achieved, and the error due to the reaction of dichromate with the HF is nullified.

It seemed that the prolonged contact overnight with the acids might be more efficient in breaking up some of the refractory minerals than would the 10 to 20 minutes of acid treatment by the conventional method. In the case of tourmaline and staurolite this did not prove to be so as it was obvious that there was practically no attack of the samples. However, the breakup of the garnets was completely satisfactory using the proposed method and a distinct improvement over the conventional method with which two, and for the spessartite three, acid treatments were required.

Hydrochloric acid was tried instead of sulfuric acid in effecting solution of the sample. The difference in the results between the two acids on samples of granite, diabase, and andradite was not significant. In each case the hydrochloric breakup gave a slightly higher figure. Erratic results on the spessartite, almandite, and ferrous ammonium sulfate crystals indicated that when hydrochloric acid is used the results are not dependable.

\section{REFERENCES}

Fairbairn, H. W., and others, 1951, A cooperative investigation of precision and accuracy in chemical, spectrochemical, and modal analysis of silicate rocks : U.S. Geol. Survey Bull. 980, 71 p.

Groves, A. W., 1951, Silicate analysis, $2 d$ ed: London, George Allen and Unwin Ltd., 336 p.

Hillebrand, W. F., Lundell, G. E. F., Bright, H. A., and Hoffman, J. I., 1953, Applied inorganic analysis, 2d ed: New York, John Wiley \& Sons, Inc., $1034 \mathrm{p}$.

Jackson, P. J., 1957, Determination of ferrous iron in pulverized fuel ash and slags from pulverized fuel-fired boilers: Appl. Chemistry, v. 7, p. 605-610.

Kondrakhina, E. G., and Songina, O A., 1958, The determination of chromium oxide, total iron oxide, and ferrous oxide in chromite ores and in chromemagnesite refractories: Trudy Inst. Stroitel. i Stroĭmaterialov, Akad. Nauk Kazakh. SSR, v. 1, p. 149-159.

Pabst, Adolph, 1943, Large and small garnets from Fort Wrangell, Alaska : Am. Mineralogist, v. 28, p. 233-245.

Wilson, A. D., 1955, A new method for the determination of ferrous iron in rocks and minerals: Great Britain Geol. Survey Bull., v. 9, p. 56-58. 


